\title{
Seed spacing variability reduces common bean yield ${ }^{1}$
}

\author{
Mateus Bortoluzi Bisognin ${ }^{2}$, Osmar Henrique de Castro Pias ${ }^{3}$,
} André Luis Vian ${ }^{4}$, Claudir José Basso ${ }^{2}$, Antônio Luis Santi ${ }^{2}$

\section{ABSTRACT}

An uneven seed spacing in the sowing row increases the plants intraspecific competition for environmental resources, potentially lowering grain yields. This study aimed to assess the yield and yield components of common bean plants, as a function of coefficients of variation $(0 \%, 20 \%, 40 \%$ and $60 \%)$ of seeds in the sowing row. The main yield components, plant traits and grain yield were evaluated. The yield component that best explains the seed spacing variability on grain yield is the number of grains per plant $(r=0.94)$. Grain yield declines linearly as the seed spacing variability increases: $81.5 \mathrm{~kg} \mathrm{ha}^{-1}(4.4 \%)$ for every $10 \%$ increase in the coefficient of variation. Thus, a less longitudinal seed spacing variability contributes to achieving higher grain yields.

KEYWORDS: Phaseolus vulgaris, longitudinal seed distribution, plant arrangement.

\section{INTRODUCTION}

Brazil ranks second in common bean (Phaseolus vulgaris L.) consumption (Brasil 2016) and is the third largest producer, with a planted area of approximately 3.14 million hectares in the 2017/2018 growing season (Conab 2018). As such, common bean plays a vital social and economic role, in Brazil.

The main bean-producing states are Paraná (22.5\%), Minas Gerais (18.9\%), Mato Grosso $(9.0 \%)$ and Bahia $(8.4 \%)$, but the crop is grown in almost every state, incorporating different cultivation systems, technology levels and planting times in

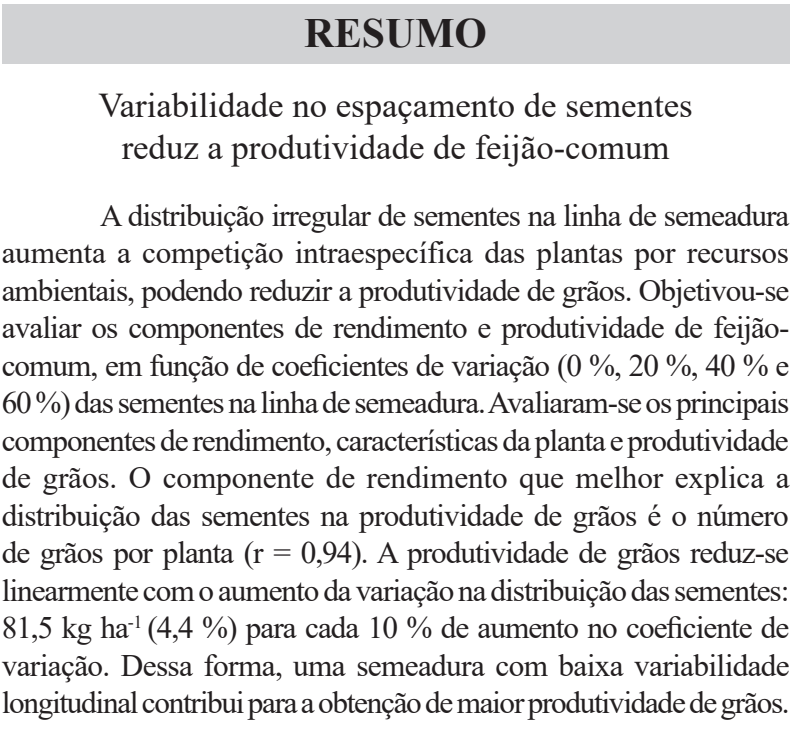

PALAVRAS-CHAVE: Phaseolus vulgaris, distribuição longitudinal de sementes, arranjo de plantas.

a range of soil and climate conditions (Pereira et al. 2009). In recent years, the practice of growing common bean after harvesting maize and soybean crops, known as succession planting, has become popular in the Rio Grande do Sul state.

The more uniform the seed spacing, the lower is the intraspecific competition between plants for water, light and nutrients, thereby ensuring higher grain yields (Heiffig et al. 2006). As a result, determining the coefficient of variation for longitudinal seed distribution in crops is an important tool, because it determines the magnitude of its effect on grain yield (Horbe 2015).

1. Received: Sep. 26, 2018. Accepted: Mar. 01, 2019. Published: Apr. 22, 2019. DOI: 10.1590/1983-40632019v4955134.

2. Universidade Federal de Santa Maria, Departamento de Ciências Agronômicas e Ambientais, Frederico Westphalen, RS, Brasil.E-mail/ORCID: mateusbisognin@hotmail.com/0000-0002-8772-097X, claudirbasso@gmail.com/0000-0002-3013-5702, santi_pratica@yahoo.com.br/0000-0002-4773-4912.

3. Universidade Federal do Rio Grande do Sul, Departamento de Solos, Porto Alegre, RS, Brasil. E-mail/ORCID: henriquepias@yahoo.com.br/0000-0003-0325-3452.

4. Universidade Federal do Rio Grande do Sul, Departamento de Plantas de Lavoura, Porto Alegre, RS, Brazil. E-mail/ORCID: andre.vian@ufrgs.br/0000-0002-9781-1533. 
The importance of a good plantability in achieving high yields has been reported for soybean (Bertelli et al. 2016) and maize (Vieira Junior et al. 2006, Horbe 2015). Bean crops can exhibit yield component compensation under smaller-thanrecommended plant densities in the form of greater branching (Ribeiro et al. 2004). However, when plant spacing is determined based on high coefficients of variation, this compensation effect may not be sufficient, because the short distance between plants will result in a large number of dominant and underdeveloped plants. Additionally, common bean has high nutrient requirements, shallow root system and short growth cycle, factors that undermine the compensation effect (Rosolem \& Marubayashi 1994). As such, this study aimed to assess the yield and yield components of common bean plants, as a function of seed coefficients of variation within rows.

\section{MATERIAL AND METHODS}

The experiment was conducted in Jaboticaba $\left(27^{\circ} 38^{\prime} 35^{\prime} \mathrm{S}, 53^{\circ} 17^{\prime} 05^{\prime \prime} \mathrm{W}\right.$ and average altitude of $560 \mathrm{~m}$ ), Rio Grande do Sul state, Brazil, in 2017. The climate in the region is humid subtropical (Cfa), according to the Köppen's classification. The average annual rainfall is around 2,100 $\mathrm{mm}$ and the average annual temperature is $17-18^{\circ} \mathrm{C}$, reaching more than $22^{\circ} \mathrm{C}$ in the hottest month and ranging from $-3^{\circ} \mathrm{C}$ to $18^{\circ} \mathrm{C}$ in the coldest one (Maluf 2000).
The soil in the area is classified as a Dystrophic Red Latosol (Oxisol) (Santos et al. 2013). The experimental area has been under a no-tillage system since 2003, rotating soybean (Glycine max L.) and maize (Zea mays L.) in the summer and wheat (Triticum aestivum L.) and white oat (Avena sativa L.) in the winter. The soil analysis performed at the 0.00-0.10 m layer identified the following physical and chemical attributes: $53 \%$ of clay; $\mathrm{pH}$ in water of $5.9 ; 17.0 \mathrm{mg} \mathrm{dm}^{-3}$ of phosphorus (Mehlich 1); $82.5 \mathrm{mg} \mathrm{dm}^{-3}$ of potassium; $70.3 \%$ of base saturation; $2.4 \%$ of organic matter; and effective cation exchange capacity of $10.1 \mathrm{cmol} \mathrm{dm}^{-3}$.

A randomized block design was used, with four repetitions. Four levels of seed spatial distribution were assessed, corresponding to coefficients of variation of $0 \%, 20 \%, 40 \%$ and $60 \%$. The $0 \%$ treatment applied an equidistant plant spacing of $10 \mathrm{~cm}$, representing an optimal population and row spacing of 222,222 plants ha ${ }^{-1}\left(10\right.$ plants $\left.\mathrm{m}^{-1}\right)$ and $0.45 \mathrm{~m}$, respectively. For the remaining treatments with spatial distribution errors $(20 \%, 40 \%$ and $60 \%$ ), calculations were based on predetermined plant spacing to find the respective coefficients of variation (Figure 1). The plots consisted of five $3 \mathrm{~m}$-long rows, totaling $6.75 \mathrm{~m}^{2}$. The three center rows of each plot, excluding $0.5 \mathrm{~m}$ at the end of each row, were used as the study area to assess grain yield and its components.

The seeds were previously treated with the insecticides imidacloprid and fipronil and the

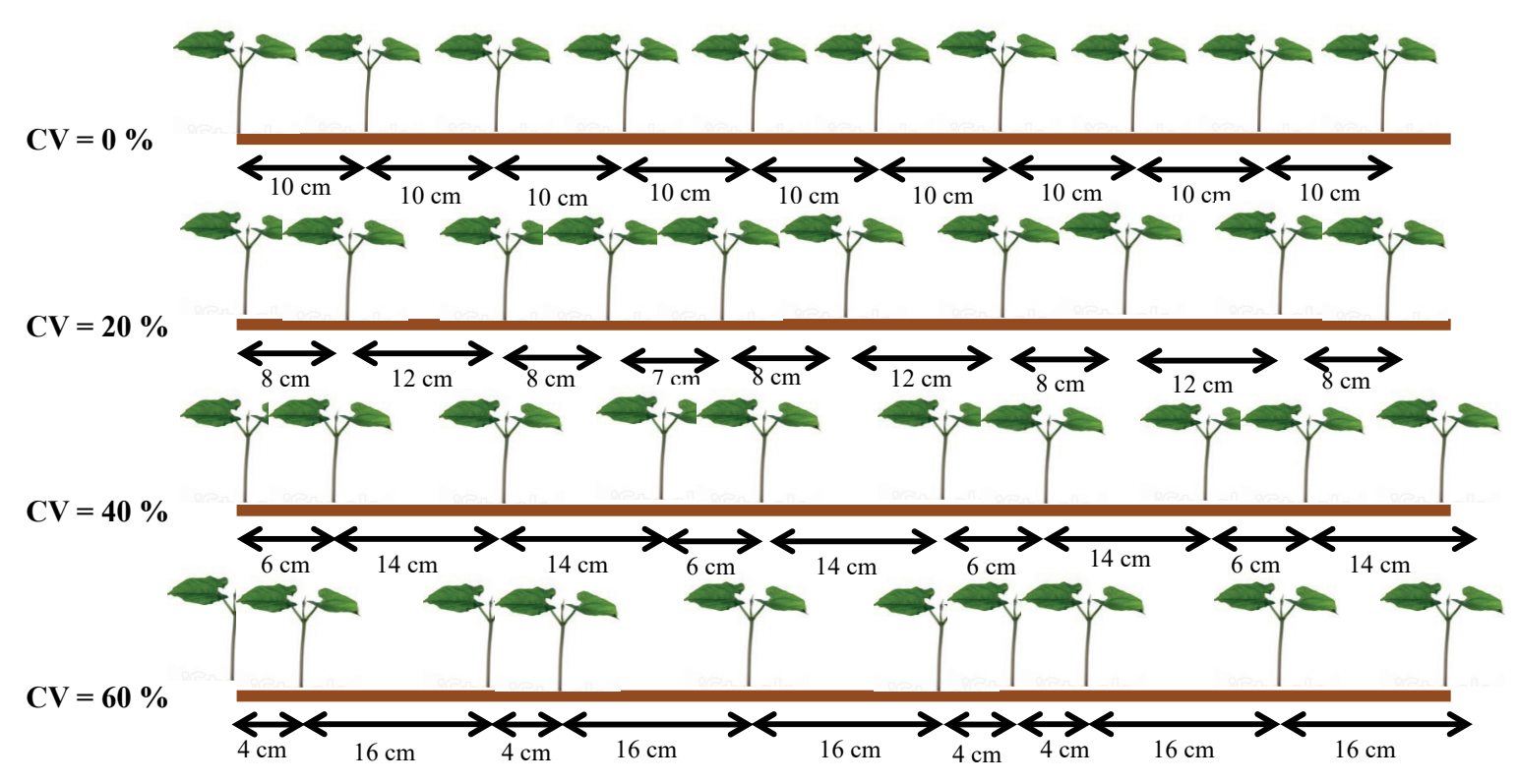

Figure 1. Spatial distribution of common bean plants, as a function of coefficients of variation (CV). 
fungicide carbendazim + thiram, to control pests and diseases at the beginning of the growth cycle. Planting was carried out on 01 February 2017, using the IPR Tuiuiú cultivar. Mechanized furrow opening was performed, string marked with the predetermined distances of each treatment was placed along the rows, and two seeds were planted at each indicated location.

Fertilization was determined according to official recommendations for the crop (CQFS-RS/ SC 2016), applying $250 \mathrm{~kg} \mathrm{ha}^{-1}$ of NPK 08-20-20 formulation to achieve a yield of $2,500 \mathrm{~kg} \mathrm{ha}^{-1}$. Plant emergence occurred at 10 days after planting. The plots were thinned at 13 days after emergence (DAE), leaving one plant per spacing to obtain the desired plant density. Nitrogen was manually applied to the topsoil ( $54 \mathrm{~kg} \mathrm{ha}^{-1}$ of $\mathrm{N}$ with urea as source) at 25 DAE. Daily and accumulated rainfall during the experiment are shown in Figure 2.

Manual harvesting was carried out on 29 May 2017, and the grain yield and 1,000-seed weight were calculated by counting and weighing eight repetitions of 100 seeds. Yield components and plant traits were assessed by collecting 10 plants from the central row of the study area in each plot and obtaining an average for the following: plant height; first pod insertion height; number of branches; number of pods per branch; number of pods on the main stem; and number of seeds per plant.

The data were submitted to analysis of variance, using the F-test at $5 \%$ of significance. Regression analysis $(p<0.05)$ was performed for significant treatments to quantify the effect of spatial variability on grain yield and its components. The Pearson's correlation coefficient was also applied

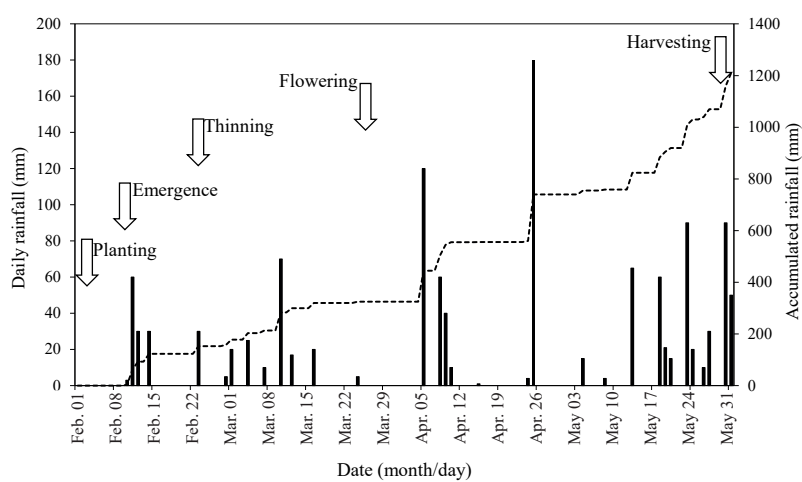

Figure 2. Daily and accumulated rainfall during the growth cycle of the common bean succession crop in Jaboticaba, Rio Grande do Sul state, Brazil, in 2017.
( $\mathrm{p}<0.05$ ), using the SAS 9.0 software (SAS Institute Inc., USA) for all the analyses.

\section{RESULTS AND DISCUSSION}

No significant differences were observed for number of pods on the main stem and 1,000-seed weight as a function of seed spacing, with average values of 7.70 and $219.93 \mathrm{~g} / 1,000$ seeds, respectively. This is because these traits are affected more by genetics (Araújo et al. 2013) and environmental conditions (Arf et al. 1996) than by management practices, particularly in terms of coefficients of variation for seed spacing. These results were confirmed by Hawerroth et al. (2011), who found that the 1,000-seed weight is less correlated with yield than other variables, such as number of seeds per area.

In general, the yield obtained was high, considering the adverse climate conditions during the field experiment, with drought from March to April (flowering) and high rainfall at harvesting (Figure 2). Nevertheless, the adjusted $\mathrm{R}^{2}$ indicated a yield of $1,837 \mathrm{~kg} \mathrm{ha}^{-1}$ for the $0 \%$ treatment, $33.5 \%$ higher than the average yield for succession common bean crops in the Rio Grande do Sul state in 2017, and $21.7 \%$ higher than the national average (Conab 2018).

Grain yield was significantly influenced by seed spacing variability (Figure 3a), with minimum and maximum values of $1,348 \mathrm{~kg} \mathrm{ha}^{-1}$ and $1,837 \mathrm{~kg} \mathrm{ha}^{-1}$, respectively, corresponding to a $26.6 \%$ decline in yield at the $60 \%$ treatment, when compared to the control $(0 \%)$.

The decrease of around $163 \mathrm{~kg} \mathrm{ha}^{-1}(8.9 \%)$ of grains for every $20 \%$ increase in the coefficient of variation can be explained by the fact that a wellspaced plant population ensures a better use of water, light and nutrients, preventing the emergence of dominant and underdeveloped plants and allowing the crop to achieve its yield potential (Maddonni \& Otegui 2006).

Another factor that may result in dominant and underdeveloped plants is planting depth, which is difficult to control due to varying soil profiles and/ or problems adjusting seeders. The time between planting and emergence is longer in seeds planted at greater depths, favoring the intraspecific competition. The combination of uneven seed spacing and planting depth variability may exacerbate the negative effects on grain yield (Silveira et al. 2018). 

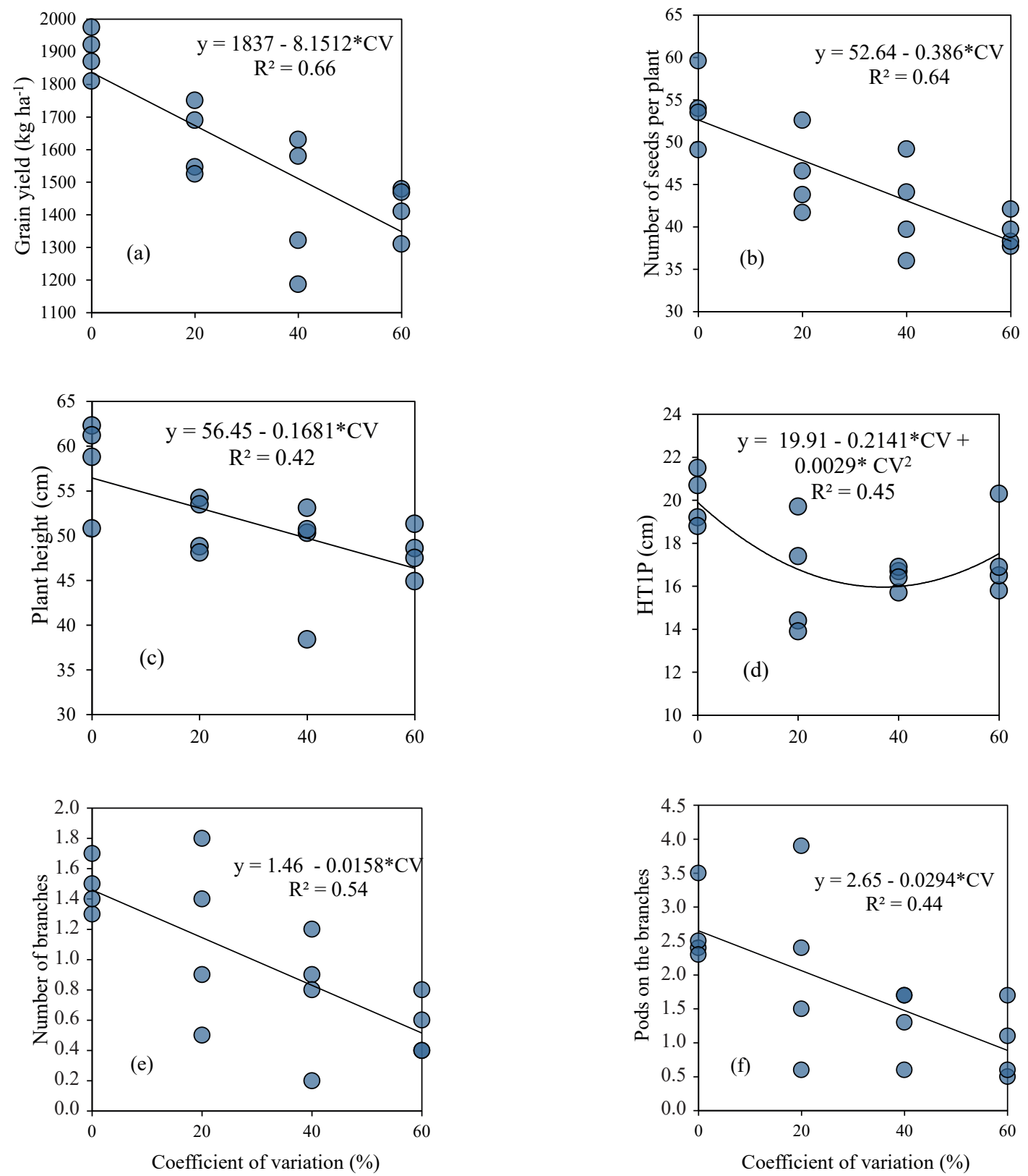

Figure 3. Grain yield (a), number of seeds per plant (b), plant height (c), first pod insertion height (HT1P) (d), number of branches (e) and number of pods on the branches (f), as a function of coefficients of variation for seed spacing.

Sangoi et al. (2012) found that an increase in within-row spatial distribution negatively affects grain yield in maize. Additionally, Horn (2010) observed that plant spacing above $30 \%$ of the coefficient of variation is common in maize crops and, in some cases, may be greater than $60 \%$, since this variable is related to the quality of planting practices, soil conditions and equipment used.

In the present study, a $20 \%$ distribution error (coefficient of variation of $20 \%$ ), considered a good quality spacing by Nummer Filho (2011) for maize crops, resulted in a common bean yield of $1,673 \mathrm{~kg} \mathrm{ha}^{-1}, 8.9 \%$ lower than that obtained in the control ( $0 \%$ variability). As such, it is important to apply the lowest possible coefficient of variation values for plant spacing, since common bean yield declines linearly as variability rises, with percent errors always resulting in production losses.

In a two-year case study, Hörbe (2015) assessed the effect of plant spacing errors in 5-plant 
transects and recorded a $1,356 \mathrm{~kg} \mathrm{ha}^{-1}$ decline in the maize yield in the 2012/2013 growing season and $815 \mathrm{~kg} \mathrm{ha}^{-1}$ in $2013 / 2014$, for every $10 \%$ increase in the coefficient of variation.

The number of seeds per plant declined linearly with the rise in the spacing errors (coefficient of variation), whereby the $0 \%$ treatment produced the best result of 53 seeds plant ${ }^{-1}$ (Figure $3 b$ ). The lowest result recorded was 38 seeds plant ${ }^{-1}$ for a coefficient of variation of $60 \%$. A reduced grain yield per plant is expected, due to the level of intraspecific competition that occurs between poorly spaced plants, resulting in a greater flower and pod abortion, and directly affecting the yield potential (Bezerra et al. 2008).

The average plant height (Figure 3c) declined as the spacing variability increased, with values of $56 \mathrm{~cm}, 53 \mathrm{~cm}, 49 \mathrm{~cm}$ and $46 \mathrm{~cm}$ for the coefficients of variation of $0 \%, 20 \%, 40 \%$ and $60 \%$, respectively. Simone et al. (1992) reported that a plant height greater than $50 \mathrm{~cm}$ is needed for mechanical harvesting. It is important to underscore that tall plants tend to exhibit high lodging indices, but this effect was not observed, even in the $0 \%$ treatment (tallest plants). It was noticed, in the present study, that well-spaced plants are taller, what results in greater first pod insertion heights.

The first pod insertion height (Figure 3d) is a significant trait in common bean crops and, since the higher pods are off the ground, the easier it is to apply crop treatments and maintain the less direct contact they have with the soil, thus ensuring healthier seeds (Salgado et al. 2012). In general, plant breeders select genotypes with a first pod insertion height value of around $15 \mathrm{~cm}$ for mechanical harvesting. Carvalho et al. (2010) reported a minimum first pod insertion height of $10 \mathrm{~cm}$ to facilitate harvesting and avoid grain losses.
The number of branches and number of pods per branch were influenced by spacing variability (Figure 3e), whereby higher number of branches and number of pods per branch values (1.5 and 2.6 , respectively) were obtained with uniform seed spacing (coefficient of variation of $0 \%$ ). These components also influenced grain yield, since high values resulted in a larger number of seeds per plant. A $20 \%$ distribution error $(20 \%$ treatment) led to a decline of approximately 0.4 branches per plant and 0.6 pods on the branches, while reductions of 0.8 branches per plant and 1.5 pods on the branches were recorded for the coefficient of variation of $40 \%$, considered average seed spacing by Nummer Filho (2011). The lowest number of branches and number of pods per branch values ( 0.5 and 0.9 , respectively) were recorded in the $60 \%$ treatment, considered high seed spacing variability (Figure 3f).

Identifying traits with the greatest influence on grain yield is a priority in common bean research (Coimbra et al. 1999). The first pod insertion height showed an intermediate positive correlation with plant height $(\mathrm{r}=0.57)$, indicating that tall plants tend to exhibit a high first pod insertion height (Table 1). This is important because these variables are a barrier to mechanical harvesting, making it difficult to expand the crop to larger planted areas, since most common bean cultivars exhibit low first pod insertion heights, concentrated in the lower two thirds of the plant, increasing harvest losses and reducing grain yields (Silva \& Bevitori 1994). However, the environment is known to have a significant influence on plant architecture (Moreto et al. 2007).

The number of seeds per plant exhibited a high correlation with plant height $\left(\mathrm{r}=0.78^{*}\right)$, number of branches $\left(r=0.90^{*}\right)$, number of pods per branch $\left(\mathrm{r}=0.81^{*}\right)$ and number of pods on the main stem

Table 1. Pearson's correlation between grain yield and yield components in a common bean succession crop, as a function of coefficients of variation, for seed spacing.

\begin{tabular}{lccllllll}
\hline & HT & HT1P & NB & PBR & NPS & NSP & 1,000 SW & YLD \\
\hline HT & - & $0.57^{*}$ & $0.63^{*}$ & 0.49 & $0.71^{*}$ & $0.78^{*}$ & -0.49 & $0.78^{*}$ \\
HT1P & & - & 0.06 & 0.04 & 0.29 & 0.33 & -0.12 & $0.50^{*}$ \\
NB & & - & $0.93^{*}$ & 0.54 & $0.90^{*}$ & -0.30 & $0.79^{*}$ \\
NPB & & & - & - & 0.43 & $0.81^{*}$ & -0.02 & $0.73^{*}$ \\
NPS & & & & & - & $0.74^{*}$ & -0.37 & $0.67^{*}$ \\
NSP & & & & & & - & -0.22 & $0.94^{*}$ \\
1,000SW & & & & & & -0.20 \\
\hline
\end{tabular}

* Significant at $5 \%$ of probability, according to the Pearson's correlation. HT: plant height; HT1P: first pod insertion height; NB: number of branches; NPB: number of pods per branch; NPS: number of pods on the main stem; NSP: number of seeds per plant; 1,000SW: 1,000-seed weight; YLD: yield. 
$\left(\mathrm{r}=0.74^{*}\right)$, indicating that the tallest plants with the largest number of branches, nodes and pods tend to have more seeds per plant.

The 1,000-seed weight variable showed an intermediate negative correlation with number of branches $(r=-0.30)$. The former tends to have more branches due to the larger distance between plants (high availability of environmental resources). However, our results demonstrate that most common bean pods are located on the main stem. As such, the large number of branches on dominant plants during grain filling may increase the competition for photoassimilates, reducing the seed weight and potentially lowering grain yields (Mundstock \& Thomas 2005).

Grain yield showed a strong positive correlation with plant height $\left(\mathrm{r}=0.78^{*}\right)$, number of branches $\left(\mathrm{r}=0.79^{*}\right)$, number of pods per branch $\left(\mathrm{r}=0.73^{*}\right)$, number of pods on the main stem $\left(r=0.67^{*}\right)$ and number of seeds per plant $\left(\mathrm{r}=0.94^{*}\right)$, suggesting that grain yield tends to be higher in tall plants with more branches, pods and seeds. Sousa et al. (2016) also found a positive correlation between plant height and grain yield.

In the present study, the number of seeds per plant displayed the highest correlation with yield, corroborating the findings of Teixeira et al. (2000), who reported a direct relationship between number of seeds per plant and yield. Hawerroth et al. (2011) also recorded a high correlation between number of seeds per plant and yield in common bean plants.

According to Coimbra et al. (1999), the number of pods per plant is one of the most important yield components in common bean crops. These results are consistent with those of Zilio et al. (2011), although the authors also noted that yield is a complex trait resulting from the combined action of all its components, as opposed to the individual effects of each one.

\section{CONCLUSIONS}

The yield component that best explains the effect of seed spacing variability on common bean grain yield is the number of seeds per plant $(\mathrm{r}=0.94)$. Grain yield declines linearly as seed spacing variability increases, falling $81.5 \mathrm{~kg} \mathrm{ha}^{-1}(4.4 \%)$ for every $10 \%$ increase in the coefficient of variation. Thus, a less longitudinal seed spacing variability contributes to achieving higher grain yields.

\section{REFERENCES}

ARAÚJO, A. P. et al. Produção de cultivares de feijoeiro sob sistema orgânico de produção. In: CONGRESSO BRASILEIRO DE CIÊNCIA DO SOLO, 34., 2013, Florianópolis. Anais... Available at: $<$ https://ainfo.cnptia. embrapa.br/digital/bitstream/item/88579/1/1408.pdf>. Access on: 16 Apr. 2019.

ARF, O. et al. Efeito de diferentes espaçamentos e densidades de semeadura sobre o desenvolvimento do feijoeiro (Phaseolus vulgaris L.). Pesquisa Agropecuária Brasileira, v. 31, n. 9, p. 629-634, 1996.

BERTELLI, G. A. et al. Desempenho da plantabilidade de semeadoras pneumáticas na implantação da cultura da soja no Cerrado piauiense - Brasil. Brazilian Journal of Applied Technology for Agricultural Science, v. 9, n. 1, p. 91-103, 2016.

BEZERRA, A. A. C.; TÁVORA, F. J. A. F.; FREIRE FILHO, F. R. Morfologia e produção de grãos em linhagens modernas de feijão-caupi submetidas a diferentes densidades populacionais. Revista de Biologia e Ciências da Terra, v. 8, n. 1, p. 1-9, 2008.

BRASIL. Ministério da Agricultura, Pecuária e Abastecimento. Informe econômico da política agrícola. 2016. Available at: <http://www.agricultura. gov.br/assuntos/politica-agricola/arquivos-deestatisticas/edicao-n-04-2016.pdf/view>. Access on: 20 Nov. 2018.

CARVALHO, E. R. et al. Desempenho de cultivares de soja [Glycine $\max (\mathrm{L}$.) Merril] em cultivo de verão no sul de Minas Gerais. Ciência e Agrotecnologia, v. 34, n. 1, p. 892-899, 2010.

COIMBRA, J. L. M. et al. Análise de trilha I: análise do rendimento de grãos e seus componentes. Ciência Rural, v. 29, n. 2, p. 213-218, 1999.

COMISSÃO DE QUÍMICA E FERTILIDADE DO SOLO DO RS/SC (CQFS-RS/SC). Manual de calagem e adubação para os estados do Rio Grande do Sul e de Santa Catarina. 11. ed. Porto Alegre: Sociedade Brasileira de Ciência do Solo/CQFS-RS/SC, 2016.

COMPANHIA NACIONAL DE ABASTECIMENTO (Conab). Série histórica das safras. 2018. Available at: <https://www.conab.gov.br/info-agro/safras/seriehistorica-das-safras>. Access on: 15 Nov. 2018.

HAWERROTH, F. J.; CRESTANI, M.; SANTOS, J. C. P. Desempenho de cultivares de feijoeiro sob inoculação com Rhizobium e relação entre os caracteres componentes do rendimento de grãos. Semina: Ciências Agrárias, v. 32, n. 3, p. 897-908, 2011. 
HEIFFIG, L. S. et al. Fechamento e índice de área foliar da cultura da soja em diferentes arranjos espaciais. Bragantia, v. 65, n. 2, p. 285-295, 2006.

HÖRBE, T. A. N. Distribuição espacial de plantas na fileira e sua relação com a produtividade da cultura do milho. 2015. 66 f. Tese (Doutorado em Ciência do Solo) Universidade Federal de Santa Maria, Santa Maria, 2015.

HORN, D. Qualidade de plantio: uma nova abordagem. Boletim Informativo Pioneer, v. 3, n. 1, p. 17-19, 2010.

MADDONNI, G. A.; OTEGUI, M. E. Intra-specific competition in maize: contribution of extreme plant hierarchies to grain yield, grain yield components and kernel composition. Field Crops Research, v. 97, n. 2-3, p. 155-166, 2006.

MALUF, J. R. T. Nova classificação climática do estado do Rio Grande do Sul. Revista Brasileira de Agrometeorologia, v. 8, n. 1, p. 141-150, 2000.

MORETO, A. L. et al. Estimação dos componentes da variância fenotípica em feijoeiro utilizando o método genealógico. Ciência e Agrotecnologia, v. 31, n. 4, p. 10351042, 2007.

MUNDSTOCK, C. M.; THOMAS, A. L. Soja: fatores que afetam o crescimento e o rendimento de grãos. Porto Alegre: Ed. UFRGS, 2005.

NUMMER FILHO, I. Precisão no plantio: sugestão de uma nova abordagem. 2011. Available at: <http://www. pioneersementes.com.br/palestrasonline $>$. Access on: 15 Jan. 2018.

PEREIRA, H. S. et al. Comparação de métodos de análise de adaptabilidade e estabilidade fenotípica em feijoeiro comum. Pesquisa Agropecuária Brasileira, v. 44, n. 4, p. 374-383, 2009.

RIBEIRO, N. D. et al. Alterações em caracteres agromorfológicos em função da densidade de plantas em cultivares de feijão. Revista Brasileira de Agrociência, v. 10, n. 2, p. 167-173, 2004.
ROSOLEM, C. A.; MARUBAYASHI, O. M. Seja o doutor do seu feijoeiro. Informações Agronômicas, n. 68, p. 1-4, 1994.

SALGADO, F. H. M. et al. Efeito do nitrogênio em feijão cultivado em terras altas no sul do estado do Tocantins. Ambiência, v. 8, n. 1, p. 125-136, 2012.

SANGOI, L. et al. Variabilidade na distribuição espacial de plantas na linha e rendimento de grãos de milho. Revista Brasileira de Milho e Sorgo, v. 11, n. 3, p. 268-277, 2012.

SANTOS H. G. et al. Sistema brasileiro de classificação de solos. 3. ed. Brasília, DF: Embrapa, 2013.

SILVA, C. C.; BEVITORI, R. Colheita e beneficiamento de feijão. Informe Agropecuário, v. 17, n. 178, p. 63-65, 1994.

SILVEIRA, P. M.; NASCENTE, A. S.; SILVA, J. G. The effect of longitudinal distribution and seed depth on grain yield of common bean. Journal of Seed Science, v. 40, n. 1, p. 90-97, 2018.

SIMONE, M. et al. Adaptación de variedades y líneas de judias secas (Phaseolus vulgaris L.) a la recolección mecanica directa. Salta: INTA, 1992.

SOUSA, S. A. de et al. Comportamento de genótipos de feijão comum sob estresse de nitrogênio no Cerrado. Brazilian Journal of Applied Technology for Agricultural Science, v. 9, n. 2, p. 53-62, 2016.

TEIXEIRA, I. R. et al. Resposta do feijoeiro comum (Phaseolus vulgaris L. cv. Pérola) a diferentes densidades de semeadura e doses de nitrogênio. Ciência e Agrotecnologia, v. 24, n. 2, p. 399-408, 2000.

VIEIRA JUNIOR, P. A. et al. População de plantas e alguns atributos do solo relacionados ao rendimento de grãos de milho. Acta Scientiarum Agronomy, v. 28, n. 4, p. 483-492, 2006.

ZILIO, M. et al. Contribuição dos componentes de rendimento na produtividade de genótipos crioulos de feijão (Phaseolus vulgaris L.). Revista Ciência Agronômica, v. 42, n. 2, p. 429-438, 2011. 